\title{
Suvremeno iseljavanje iz Hrvatske u Irsku s posebnim osvrtom na mlade iz Slavonije
}

DOI: https://doi.org/10.11567/met.33.3.1

UDK: $314.743(417=163.42)$

331.55(417=163.42)

Prethodno priopćenje

Primljeno: 14.09.2017.

Prihvaćeno: 16.02.2018.

\section{Marijeta Rajković Iveta}

Odsjek za etnologiju i kulturnu antropologiju, Filozofski fakultet Sveučilišta u Zagrebu, Zagreb

mrajkovi@ffzg.hr

\section{Tea Horvatin}

Našice

teahorvatin7@gmail.com

\section{SAŽETAK}

Nakon ulaska Republike Hrvatske u Europsku uniju pojavio se trend iseljavanja u Republiku Irsku. Iseljavanje su potaknuli makropolitički (ulazak Republike Hrvatske u Europsku uniju i otvoreno tržište rada) i makroekonomski kontekst (gospodarski razvoj Irske). Istraživanje je dalo jako različite hrvatske i irske podatke o broju hrvatskih građana u Irskoj. Rad se temelji na etnološkoj i kulturnoantropološkoj kvalitativnoj metodologiji. Prikazuju se iskustva deset migranata o tome gdje su se informirali o mogućnostima života i rada u Irskoj, kako su se i koliko dugo pripremali za odlazak te koje su administrativne procedure prolazili nakon dolaska u Irsku. Istraživanje je provedeno na mladim, uglavnom visokoobrazovanim Slavoncima koji u Irskoj rade nekvalificirane i nisko vrednovane poslove. Osim glavnoga ekonomskog motiva iseljavanja ističu se psihološka nezadovoljstva, pozitivna iskustva prijašnjih migranata, mogućnost brzog pronalaska posla, jednostavna birokracijska procedura, znanje engleskog jezika itd. Rad pokazuje veliku ulogu društvenih migrantskih mreža te komunikacijskih tehnologija i društvenih platformi.

KLJUČNE RIJEČI: Hrvati u Irskoj, iseljavanje iz Slavonije, suvremene migracije, iskustva (e)migranata 
Ja kad sad dođem u kafić, od nas 10 koji bismo se znali srest, samo jedan stalno živi u Županji, svi drugi su negdje otišli! (Dario, r. 1988., povjesničar, iselio se u Irsku)

\section{UVOD}

Iako su suvremene migracije iz Hrvatske u Irsku aktualna društvena tema, do sada nisu bile izrazito u fokusu znanstvenih istraživanja. Polazište za ovaj rad bila je upravo sveprisutnost te teme u medijima, koji kao specifičnu grupu migranata ističu mlade iz Slavonije. Cilj rada jest istražiti kontekst i opseg suvremenog vala iseljavanja iz Hrvatske u Irsku te saznati kada je i zašto Irska postala popularno odredište hrvatskih građana, posebice mladih iz Slavonije. Iseljavanje iz Republike Hrvatske u Republiku Irsku promatrat će se kroz makroekonomski i makropolitički kontekst. Rad počinje pregledom i usporedbom statističkih podataka o iseljavanju iz Hrvatske u Irsku, odnosno ulasku hrvatskih građana na irsko tržište rada. Nakon toga istražuju se posrednici u migracijskom procesu (međunarodne agencije za zapošljavanje, prijašnji migranti i društvene migrantske mreže te uloga globalnih komunikacijskih tehnologija i društvenih platformi). Naglasak rada je na etnografiji pojedinačnoga. Zanimala su nas iskustva - gdje su se migranti informirali o mogućnostima života i rada u Irskoj, kako su se i koliko dugo pripremali za odlazak te koje su administrativne procedure prolazili nakon dolaska u Irsku.

\subsection{Teorijski okvir}

$\mathrm{U}$ istraživanju migracija teorije se razlikuju po dva temelja pristupa. Jedne su proizašle iz teorije modernizacije, a druge iz povijesno-strukturalističke perspektive koja se odnosi na političku ekonomiju i utjecaj globalnoga kapitalizma. Prve naglasak stavljaju na pitanja zašto i tko migrira kao aktivni subjekt, a druge migrante smatraju pasivnim subjektima kojima manipulira svjetski ekonomski poredak (usp. Brettell i Hollifield, 2000). Noviji pristupi manje se fokusiraju na opće teorije, a više na specifičnosti određene migracije (usp. Heisler, 1992 prema Levellen, 2002: 131). U ovome se radu isto više usmjerava istraživanje migracija iz perspektive novijih pristupa iako je djelomično upotrijebljena i teorija proizašla iz teorija modernizacije - teorija potisno-privlačnih faktora, koja se razvila iz neoklasičnih ekonomskih pristupa (usp. Grbić Jakopović, 2014: 23). 
Rad se temelji na teoriji migracijskih sustava, koju karakterizira fokus na inter/regionalnim iskustvima temeljenima u međudržavnoj suradnji, domeni masovne kulture, obiteljskim i socijalnim mrežama (usp. Grbić Jakopović, 2014: 27). Iseljavanje u Irsku promatrano je kroz interakcije makro-, mikro- i mezostruktura (usp. Castles i Miller, 2003; Bretell i Hollifield, 2000). Makrostrukture su promatrane kroz makropolitički (ulazak Republike Hrvatske u Europsku uniju) i makroekonomski kontekst (usporedba gospodarstava Hrvatske i Irske) te temeljene na analizi statističkih podataka o migracijama u obje države. Etnografska građa, odnosno iskustva imigranata/kazivača prikupljena su putem intervjua i pisanim putem te čine temelj za proučavanje mikrostrukture. Osim što su mezostrukture, posrednici između makro- i mikrokonteksta, prikazane na primjeru agencija, $\mathrm{u}$ radu se propituje i uloga društvenih mreža kao posrednika. Budući da u novije vrijeme navedena teorija često stavlja fokus na proučavanje distribucije informacija, koja je "zahvaljujući suvremenim komunikacijskim tehnologijama sve brža i efikasnija « (Grbić Jakopović, 2014: 28), takav naglasak prisutan je i u ovom radu. Navedena znanja nazivaju se društvenim kapitalom, koji oblikuju i neformalne mreže osobnih odnosa, obitelj, prijateljstva i veze s lokalnom zajednicom, odnosno individualna iskustva migranata (Grbić Jakopović, 2014: 28).

\subsection{Metodologija}

U ovom radu upotrijebljen je dio rezultata opširnijeg istraživanja. Istraživanje je obuhvatilo i život u Irskoj (nalaženje posla i smještaja te razlike između života u Hrvatskoj i Irskoj), transnacionalne prakse, planove itd. Rad se temelji na etnološkoj i kulturnoantropološkoj kvalitativnoj metodologiji. Cilj je bio provesti intervjue s iseljenicima. Budući da zbog financijske nemogućnosti nismo mogle otići $\mathrm{u}$ Irsku, s kazivačima smo razgovarale tijekom njihova posjeta Hrvatskoj te virtualno. Virtualno terensko istraživanje provedeno je stupanjem u kontakt s kazivačima i prikupljanjem informacija putem suvremene tehnologije, i to razgovarajući preko Skypea, dopisivanjem te pretraživanjem portalâ. Dakle terensko istraživanje provedeno je unutar suvremenoga, proizvedenog, u ovom slučaju virtualnog lokaliteta, koji Arjun Appadurai (2011: 265) opisuje kao uvjetovan i izmijenjen »globalnim kulturnim tokovima«. Lokalnost vidi kao »niz veza između osjećanja društvene bliskosti, tehnologija interaktivnosti i relativnosti konteksta « (Appadurai, 2011: 265). Primjerice grupa »Idemo u Irsku« na društvenoj 
mreži Facebook odgovara takvu poimanju terena proizašlog iz propitivanja koncepta etnografskog mjesta. ${ }^{1}$ Iako je fokus istraživanja na fizičkom prostoru Slavonije, on je i virtualan, čime je postignuto »odmicanje od tradicionalnog terena, okretanje društvenim umjesto fizičkim prostorima...« (Pleše, 2006: 131). Stoga se ovo istraživanje temelji na redefiniranom terenu u skladu s razumijevanjem današnjeg svijeta novih tehnologija te mobilnosti ljudi i dobara.

Istraživanje je provedeno u razdoblju od ljeta 2015. do jeseni 2017. Budući da statistički podaci Državnog zavoda za statistiku RH pokazuju da se najviše iseljava mlado stanovništvo između 20. i 34. godine (Migracija stanovništva Republike Hrvatske u 2016., 2017) te da po broju vanjskih migranata prednjače slavonske županije, to je bila i naša ciljana skupina. Imigranti su izabrani po kriteriju prostora s kojeg su se iselili - Slavonije, ${ }^{2}$ s time da je $u$ rad uključena i jedna imigrantica iz Koprivnice (zato što se iselila i intervjuirana je zajedno s momkom iz Slavonije te su govorili o svom zajedničkom iskustvu). Devet imigranata pripada odabranoj grupi. Svi su emigrirali u Irsku prije najviše pet godina. Intervjuirano je šest žena i četiri muškarca. Svi su visokog ili višeg obrazovanja, osim jednoga kazivača sa srednjom stručnom spremom. Svi imaju prethodna različita radna iskustva u rodom gradu, mjestima studiranja ili na sezonskim poslovima na Jadranu. Jedna je osoba tijekom studija radila u SAD-u. Četvero smo već poznavale te su nam oni preporučili druge imigrante, a neki su zbog zadovoljenja kriterija pronađeni i odabrani putem Facebooka. Metodom polustrukturiranog intervjua licem u lice razgovarale smo s jednim parom. Sa sedam imigranata istraživanje smo provele pisanim putem preko privatnih poruka na Facebooku i preko elektroničkih pisama. Imigrantima su poslana pitanja na koja su odgovarali. Nakon dobivenih odgovora prema potrebi poslana su im dodatna pitanja izravnom komunikacijom. ${ }^{3} \mathrm{Uz}$ navedenu grupu imigranata, pozivima preko Skypea intervjuirana je i gospođa Andrea Vukina Stojanović. Ona i suprug odselili su se u Irsku 1998. iz Zagreba. Zajedno

1 Mjesto je, između ostaloga, definirano i kao »društveni proizvod, nastaje i održava se u interakciji niza aktera, odražava određenu društvenu stvarnost i istovremeno proizvodi stvarnost. Zato mjesto poimamo kao koncept određen interakcijama neke zajednice ili grupe [...] Mjesto lokalizira i konkretizira etnografsko istraživanje, ali je, isto tako, konstrukt koji se oblikuje kulturnim i društvenim praksama te samim etnografskim istraživanjem « (Potkonjak, 2014: 25).

2 Iz Osijeka su četiri kazivača, iz Našica dvoje te iz Novske i Županje po jedan.

3 Imena kazivača u tekstu su izmijenjena. Navodimo godinu rođenja, te zanimanje i posao koji radi u Irskoj prilikom prvog navođenja kazivača ili u drugim slučajevima kada se smatralo važnim ponoviti zbog konteksta u kojem se navodi citat. 
vode agenciju Irish Recruiter sa sjedištem u Dublinu putem koje pronalaze IT-stručnjake iz Hrvatske te posreduju pri njihovu zapošljavanju u Irskoj. ${ }^{4}$

\section{HRVATI U IRSKOJ}

Iako su se u malom broju građani Hrvatske i prije iseljavali u Irsku, jedine informacije o toj temi pronalazimo u medijima: u novinskim člancima, na internetskim portalima i blogovima, $\mathrm{u}$ televizijskim prilozima i dokumentarnim filmovima. Kada se na tražilicu Google upiše »Hrvati u Irskoj«, najstariji je podatak 2002. Od tada do danas pronašle smo više od osamdeset članaka u sljedećim novinama i na internetskim portalima: Večernji list, Jutarnji list, Glas Slavonije, tportal.hr, index.hr, croexpress.hr, sib.hr, 034portal. hr, balkans.aljazeera.hr. itd. O fenomenu velikih razmjera pisali su i regionalni portali, u kojima su ove migracije objašnjene kao dio širega regionalnog procesa (Filipović, 2015). Tema iseljavanja u Irsku dospjela je u travnju 2015. i među glavne aktualne vijesti u državi u prilogu nazvanom »Irska - obećana zemlja za Hrvate« koji je emitiran u Dneoniku HRT-a 1. Prilog je bio dio reportaže »Lakoća življenja « snimljene u Dublinu za emisiju Labirint. ${ }^{5}$ Još detaljniji prikaz poslije je dan u dokumentarnom filmu Lijepa naša Irska. ${ }^{6}$

\subsection{Suvremena iseljavanja iz Hrvatske u Irsku}

Kako bismo istražili kontekst i opseg iseljavanja, cilj je bio saznati koliko se državljana Hrvatske iselilo u Irsku. Državni zavod za statistiku svake godine objavljuje priopćenje »Migracija stanovništva Republike Hrvatske«. ${ }^{7} \mathrm{U}$ njemu se, između ostaloga, navode podaci o vanjskoj migraciji. Prema tim podacima (tablica 1) vidimo da se broj iseljenih povećava od 2011., kada se promijenila metodologija sakupljanja podataka.

$4 \quad$ Irish Recruiter je Talent Sourcing agencija sa sjedištem u Irskoj. Osnovana je nakon ulaska Hrvatske u EU. Vlasnik brenda Irish Recruiter je kompanija Portal, koja pruža servise i usluge za recrutiment-agencije (http://www.irishrecruiter.com/o-nama/). Vlasnica agencije dopustila je da u radu navedemo njeno pravo ime.

5 Prilog je emitiran 23. travnja 2015. na HRT-u 1; autorica je novinarka Nataša Ban Leskovar.

6 Dokumentarni film emitiran je 15. lipnja 2015. na HRT-u 1; autor je novinar Josip Šarić. Zbog svoje brojnosti odjeci ovog migracijskog vala u medijskom prostoru bili bi tema zasebnog rada.

7 https://www.dzs.hr/Hrv_Eng/publication/2017/07-01-02_01_2017.htm 
Tablica 1. Vanjska migracija stanovništva Republike Hrvatske

Table 1. International migration of population of the Republic of Croatia

\begin{tabular}{cccc}
\hline & $\begin{array}{c}\text { Doseljeni iz } \\
\text { inozemstva }\end{array}$ & $\begin{array}{c}\text { Odseljeni u } \\
\text { inozemstvo }\end{array}$ & $\begin{array}{c}\text { Migracijski } \\
\text { saldo }\end{array}$ \\
\hline 2007. & 14.622 & 9002 & 5620 \\
\hline 2008. & 14.541 & 7488 & 7053 \\
\hline 2009. & 8468 & 9940 & -1472 \\
\hline 2010. & 4985 & 9860 & -4875 \\
\hline $2011 .^{*}$ & 8534 & 12.699 & -4165 \\
\hline $2012{ }^{*}$ & 8959 & 12.877 & -3918 \\
\hline $2013 .^{*}$ & 10.378 & 15.262 & -4884 \\
\hline $2014 .^{*}$ & 10.638 & 20.858 & -10.220 \\
\hline $2015 .^{*}$ & 11.706 & 29.651 & -17.945 \\
\hline $2016 .^{*}$ & 13.985 & 36.436 & -22.451 \\
\hline
\end{tabular}

${ }^{*}$ Radi usklađivanja s međunarodnim standardima i pravnom stečevinom Europske unije podaci statistike vanjske migracije od 2011. obrađuju se prema novoj metodologiji.

Izvor: Migracija stanovništva Republike Hrvatske u 2016., Priopćenje 7.1.2, Državni zavod za statistiku, Zagreb, 2017, https://www.dzs.hr/Hrv_Eng/publication/2017/07-01-02_01_2017. $h t m$

Iz istih podataka saznajemo primjerice da se u 2016. godini najveći negativni migracijski saldo odnosio na Osječko-baranjsku županiju (-3634 osobe), a dvije slavonske županije Vukovarsko-srijemska (-2763 osobe) te Brodsko-posavska (-2208 osoba) u samom su vrhu po broju odseljenoga stanovništva. U 2016. iz Republike Hrvatske u inozemstvo se odselilo 36.436 osoba, nešto više muškaraca $(54,1 \%)$ nego žena $(45,9 \%)$.

U tablici 1. vidimo da je migracijski saldo stanovništva Republike Hrvatske $\mathrm{s}$ inozemstvom iz godine $\mathrm{u}$ godinu sve negativniji i 2016. iznosio je -22.451. Iseljavanje hrvatskih građana nakon ulaska RH u EU 1. srpnja 2013., u porastu je, što se najbolje vidi na predočenom grafikonu (slika 1). 
Slika 1. Migracijski saldo stanovništva Republike Hrvatske s inozemstvom od 2007. do 2016.

Figure 1. Net migration of population of Republic of Croatia with foreign countries, 2007-2016

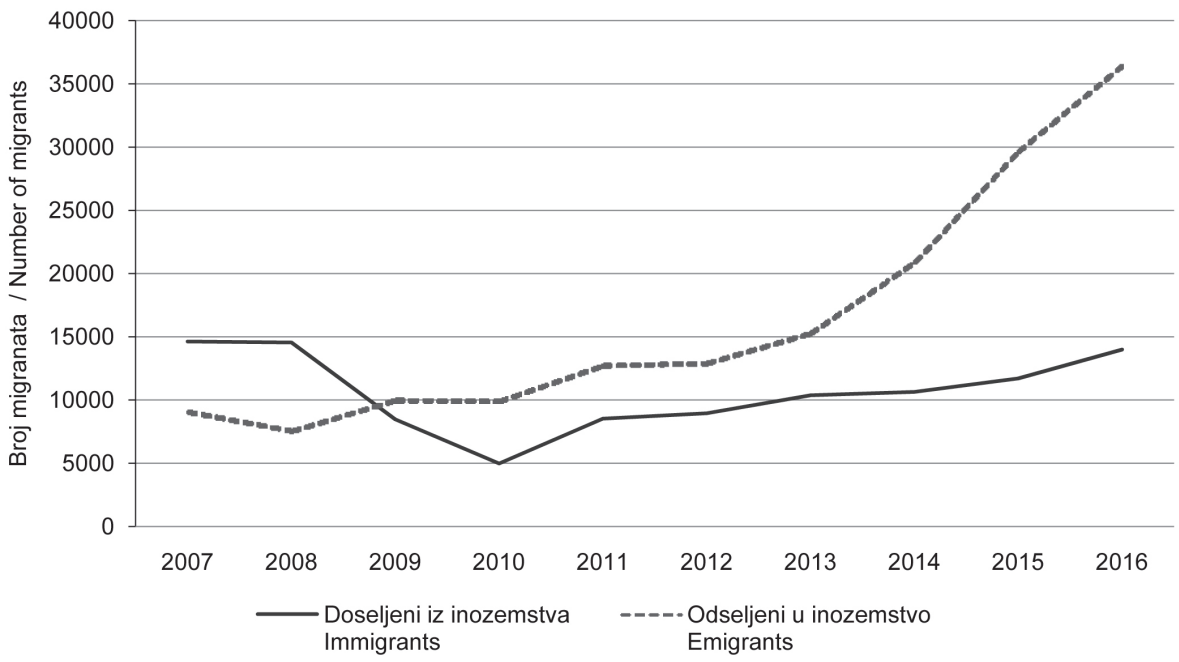

Izvor: Migracija stanovništva Republike Hrvatske u 2016., Priopćenje 7.1.2, Državni zavod za statistiku,ZZagreb, 2017, https://www.dzs.hr/Hrv_Eng/publication/2017/07-01-02_01_2017. htm

Navedeni podaci Državnog zavoda za statistiku temelje se na podacima Odjela za upravne poslove Ministarstva unutarnjih poslova (MUP), odnosno evidencijama prijava promjene prebivališta u nadležnoj policijskoj postaji. ${ }^{8}$ No smatramo da su ti podaci nedovoljno precizni jer nitko od intervjuiranih kazivača nije u policijskoj postaji prijavio odlazak. ${ }^{9}$ Kazivačica Ivona, koja je to pokušala, kazala je: »Nisam prijavila odlazak u Policijsku postaju jer su mi u istoj rekli da to nije potrebno.« Dakle istraživanje pokazuje kako je u praksi malo migranata obavljalo tu građansku dužnost, ali i da na tome ne inzistira ni policijska uprava. Osim toga odlaske hrvatskih

8 Zbog primjene Zakona o prebivalištu (Narodne novine, 144/12, 158/13) podaci uključuju osobe koje su promijenile prebivalište (http://www.dzs.hr/). Na stranicama MUP-a istaknuto je kako se Zahtjev za prijavu privremenog odlaska iz Republike Hrvatske »podnosi ako osoba napušta prebivalište $\mathrm{u}$ trajanju duljem od godinu dana [...] u policijskoj upravi ili postaji prema mjestu prebivališta ili putem diplomatske misije RH u inozemstvu « (https://www.mup.hr/gradjani/prebivaliste-i-boraviste).

9 Više o problemima vezanim uz statistička bilježenja migracija, tj. nepostojanje tzv. registra stanovništva vidi u: Grizelj i Akrap, 2011; Akrap, 2014. 
državljana u Irsku ne možemo pratiti prema podacima Državnog zavoda za statistiku jer se u podacima o vanjskim migracijama stanovništva prema zemljama odredišta Irska prvi put spominje tek 2016. (Migracija stanovništva Republike Hrvatske u 2016., 2017), i to s brojem od 1915 odseljenih hrvatskih državljana, što se, kako će se poslije u tekstu vidjeti (tablica 2), jako razlikuje od statističkih podataka u Irskoj, prema čijoj je evidenciji iste godine u Irskoj posao namjeravalo zatražiti 5312 hrvatskih građana i gdje pronalazimo podatke od 2000. Kako bismo dobile bilo kakve informacije od hrvatskih nadležnih institucija o hrvatskim državljanima u Irskoj, tijekom istraživanja kontaktirale smo Središnji državni ured za Hrvate izvan Republike Hrvatske, ${ }^{10}$ od kojeg smo dobile informaciju da ne raspolažu podacima o iseljavanju $\mathrm{u}$ Irsku te su nam predložili da kontaktiramo Veleposlanstvo Republike Hrvatske u Irskoj. No ni ono ne posjeduju te podatke.

Tablica 2. Podaci o broju hrvatskih građana koji su u Irskoj zatražili PPSbroj od 2000. do 2017.

Table 2. The number of Croatian citizens who applied for PPS number, $2000-2017$

\begin{tabular}{lr}
\hline & PPS \\
\hline $2000 .^{\text {a }}$ & 70 \\
\hline 2001. & 464 \\
\hline 2002. & 420 \\
\hline 2003. & 350 \\
\hline 2004. & 264 \\
\hline 2005. & 189 \\
\hline 2006. & 176 \\
\hline 2007. & 170 \\
\hline 2008. & 123 \\
\hline
\end{tabular}

\begin{tabular}{lr}
\hline & PPS \\
\hline 2009. & 60 \\
\hline 2010. & 51 \\
\hline 2011. & 60 \\
\hline 2012. & 86 \\
\hline 2013. & 486 \\
\hline 2014. & 2091 \\
\hline 2015. & 4342 \\
\hline 2016. & 5312 \\
\hline $2017 .{ }^{\mathrm{b}}$ & 3546 \\
\hline
\end{tabular}

a Podaci se odnose na razdoblje od 19. srpnja 2000.

${ }^{b}$ Podaci za 2017. godinu odnose se na proih devet mjeseci.

Izvor: Tablicu je izradila M. Rajković Iveta na temelju podataka irskog Vladinog ureda za zapošljavanje i socijalnu zaštitu (Department of Employment Affaris and Social Protection) dostupnih na: https://www.welfare.ie/en/Pages/Personal-Public-Service-Number-Statisticson-Numbers-Issued.aspx

10 http://www.hrvatiizvanrh.hr/ 
Na službenoj internetskoj stranici irskog Vladinog ureda za zapošljavanje i socijalnu zaštitu (Department of Employment Affaris and Social Protection) welfare.ie objavljene su statistike o PPS-broju (Personal Public Service Number) ${ }^{11}$ PPS-broj obvezan je za sve koji žele raditi i živjeti u Irskoj te su ga svi imigranti koje smo kontaktirale odmah pri dolasku u Irsku zatražili. Na navedenoj stranici među ostalim državama iz koje su imigranti zatražili PPS-broj navedena je i Hrvatska. Od srpnja 2000. do listopada 2017. PPSbroj, dakle s namjerom života i rada, zatražilo je 18.278 državljana Republike Hrvatske. ${ }^{12}$ Prema podacima u tablici 2, vidimo da se broj hrvatskih državljana koji su otišli živjeti u Irsku nakon ulaska Republike Hrvatske u Europsku uniju (1. srpnja 2013.) u samo jednoj godini povećao četiri puta (2014.) i da od tada kontinuirano raste.

\section{ZAŠTO JE IRSKA POSTALA ODREDIŠTE HRVATSKIH ISELJENIKA}

Dok se sustavno ne istraži iseljavanje iz Hrvatske u Irsku do 2013., a prije analize karakteristika Republike Irske zbog kojih je u posljednje četiri godine postala privlačna hrvatskim iseljenicima, navest ćemo primjer bračnog para koji se iselio iz Hrvatske u Republiku Irsku prije toga nedavnog vala. Kazivačica A. Vukina Stojanović preselila se 1998. sa suprugom iz Hrvatske u Dublin zbog ekonomskih i profesionalnih razloga. Njegova migracija spada u kategoriju odljeva mozgova (brain drain), a njena u obiteljsku migraciju. Budući da gotovo dvadeset godina živi u Dublinu i vodi agenciju za regrutiranje radnika, zanimalo nas je kada je primijetila pojačani dolazak iz Hrvatske:

Rekla bih nekih šest do dvanaest mjeseci od ulaska u EU. Dok je do ljudi doprla informacija da Irska dozvoljava Hrvatima rad $i$ život u Irskoj bez radnih viza $i$ dozvola, a valjda i iz društvenih medija, i onda se to nekakvim sistemom lavine sve skupa proširilo. (A. Vukina Stojanović, Irish Recruiter)

Zbog čega je upravo Irska za Hrvate, odnosno Slavonce, postala poželjna destinacija u posljednjih nekoliko godina? Razloge smo potražile u njezinu gospodarskom razvoju. Povijest Irske obilježila je visoka stopa iseljavanja. ${ }^{13}$ »Još sredinom osamdesetih godina dvadesetog stoljeća Irska je bila jedna

11 PPS-broj jest jedinstveni osobni broj potreban za transakcije između pojedinaca i ureda vlade te ostalih pružatelja javnih usluga u Republici Irskoj (http://www.welfare.ie/en/Pages/Personal-Public-Service-Number-Statistics-on-Numbers-Issued.aspx).

12 Nismo pronašle podatke koliko je hrvatskih državljana trajno ostalo živjeti u Irskoj.

13 Više o irskim migracijama vidi u: Smyth, 2011: 27-33; Legrand, 2005.- 
od najsiromašnijih i gospodarskih najnerazvijenijih zemalja Europe. Od tog razdoblja uslijedio je vrlo brz rast irskog gospodarstva [...] Zajedničko djelovanje brojnih unutarnjih i vanjskih čimbenika rezultiralo je preobrazbom irskoga gospodarstva, pogotovo u vidu liberalizacije i otvaranje domaćeg tržišta [...] fleksibilnog radnog zakonodavstva i sustava socijalne sigurnosti...« (Rančić, Rebac i Pilipović, 2010: 23). Dakle promjene negativnih migracijskih trendova Irske pratile su pozitivne transformacije njezine ekonomije koja je započela osamdesetih godina 20. stoljeća, kada je od pretežno agrikulturne ekonomije usmjerena prema modernoj ekonomiji znanja, temeljenoj na industriji visoke tehnologije. Razvoj je uvelike ovisio o stranim investitorima, odnosno nekoliko multinacionalnih kompanija koje su privukli visokoobrazovanom radnom snagom i niskim poreznim stopama (12,5\%) za korporacije (usp. Smyth, 2011: 31-33; Rančić, Rebac i Pilipović, 2010). »Članstvo u Europskoj uniji omogućilo je Irskoj uspješnu realizaciju izvozno orijentirane razvojne strategije i otvorilo vrata sredstvima iz Europskih razvojnih fondova« (Rančić, Rebac i Pilipović, 2010: 29). Irska je usmjerila svoju proizvodnju i izvoz »u najbrže rastuće gospodarske sektore [...] kao što su IT sektor, proizvodnja informatičke opreme, farmacija i kemijska industrija« (Rančić, Rebac i Pilipović, 2010: 29).

Takva strategija rezultirala je intenzivnim gospodarskim razvojem države u sljedećem desetljeću, kada je zbog dvostruko bržeg razvoja od većine ostalih država Europske unije prozvana »Keltskim tigrom«. Tijekom devedesetih godina 20. i u prvim godinama 21. stoljeća došlo je do pozitivnog obrata te se velik broj ljudi uselio u Irsku. Mnoge od tih migracija bile su povratničke migracije (usp. Smyth, 2011: 32; Legrand, 2005; Rančić, Rebac i Pilipović, 2010). Tijekom faze nacionalnog razvoja »Keltskog tigra« udvostručio se broj radno aktivnog stanovništva (usp. Smyth, 2011; Legrand, 2005; Fanning i sur., 2017). Uz Italiju, Španjolsku i Južnu Koreju Irska je suvremeni primjer kako migrantske prakse mogu pretvoriti državu iz emigracijskoga u imigracijsko odredište u samo nekoliko dekada brzoga ekonomskog rasta (usp. Martin, Abella i Kruptsch, 2006: 7). Do pojačanog iseljavanja irskog stanovništva došlo je opet 2008., kada je usporen ekonomski razvoj, a ubrzo je nastupila i recesija, no uz financijsku pomoć Europske unije i Međunarodnoga monetarnog fonda 2010. počeo je oporavak ekonomije (Fanning i sur., 2017). U posljednja dva desetljeća Irsku obilježavaju ekonomske i socijalne promjene te brojni dolasci kulturno različitih skupina emigranata (usp. Smyth, 2011: 33). Godine 2013. Irska se drugi put izvukla iz recesije, što se odrazilo i na migracije. Migracijska kretanja u posljednjih deset godina u Irskoj prikazana su na sljedećem grafikonu (slika 2). Iz njega 
je vidljivo da se od 2013. iseljavanje iz Irske smanjuje, a useljavanje povećava, što je rezultiralo 2017. najvišim migracijskim saldom (+19.800) od 2008. Osim toga prirodni prirast stanovništva (33.100 više rođenih nego umrlih) i pozitivni migracijski saldo rezultirali su ukupnim porastom broja stanovnika za 52.900, čime je procjena broja stanovnika iznosila $4.792 .500 \mathrm{u}$ travnju 2017. (Population and Migration Estimates, 2017).

Slika 2. Migracije u Irskoj od siječnja 2007. do travnja 2017.

Figure 2. Migration in Ireland, January 2007 - April 2017

200,000

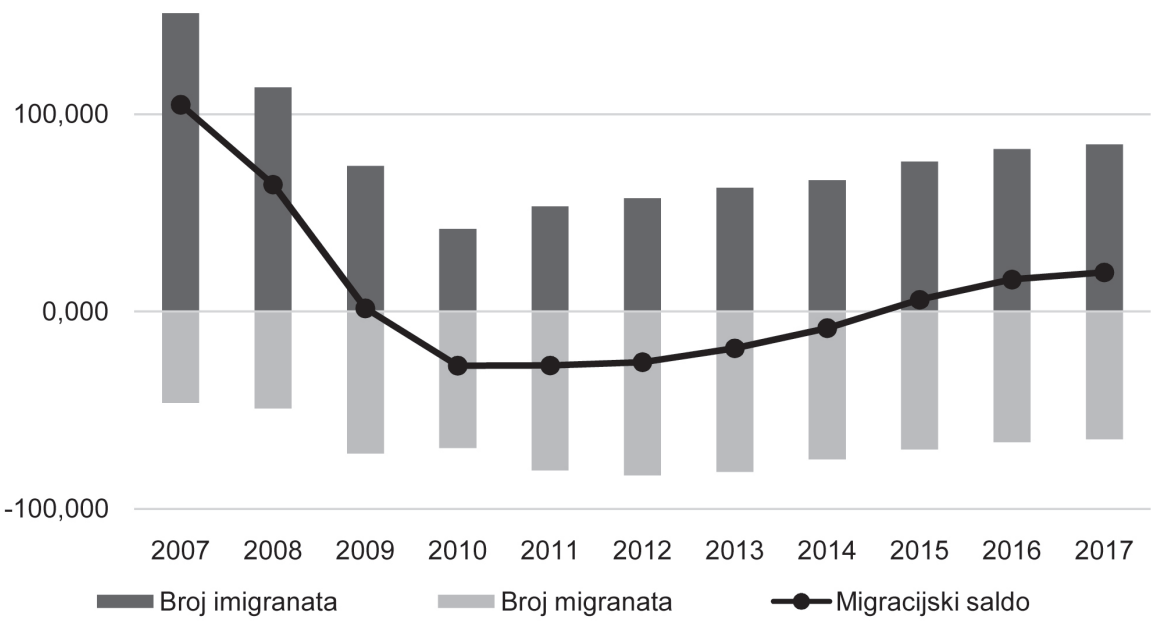

Izvor: Population and Migration Estimates, CSO statistical release, Central Statistics Office, Cork, 2017, http://www.cso.ie/en/releasesandpublications/er/pme/populationandmigrationestimatesapril2017

U usporedbi s Hrvatskom situacija je u Irskoj bolja uzmemo li u obzir samo postotak nezaposlenosti mladih, koji je primjerice u Irskoj 2015. bio 20\%, a u Hrvatskoj 43\% (Eurostat, 2016). S obzirom na nezaposlenost, negativne ekonomske trendove, pad životnog standarda, lošu poduzetničku klimu te brojne druge potisne faktore u Hrvatskoj ${ }^{14}$ je $»$ prisutno pojačano iseljavanje posebice mlade, radno i fertilno najproduktivnije populacije« (Župarić-lljić, 2016: 3).

14 Više o posljedicama ekonomske krize na tržište rada i mobilnosti rane snage u EU i RH vidi u: Obadić, 2014. 
Gospodarski oporavak, koji posljednjih nekoliko godina obilježava Irsku, te iseljavanje domaćeg stanovništva otvorili su mnoge prilike za zapošljavanje stranaca. Prema analiziranim statistikama među ljudima koji su u Irskoj zatražili PPS-broj mnogo je Poljaka, Bugara, Rumunja, Brazilaca, Španjolaca, Francuza, Amerikanaca itd. ${ }^{15}$ Prema podacima dobivenim od naših sugovornika, najviše poslova nudi se u nekvalificiranim, nisko vrednovanim (tipično imigrantskim) poslovima poput rada u ugostiteljstvu i trgovini. Na poslovima poput pranja suđa, konobarenja i čišćenja može se mjesečno zaraditi između 1500 i 2000 eura. Mnogi hrvatski građani s visokim obrazovanjem koji su obuhvaćeni ovim istraživanjem pronalaze upravo takve poslove, izvan svoje struke, no iako to ne planiraju raditi čitav život, u početku ih prihvaćaju zbog redovite tjedne plaće s kojom mogu živjeti bolje nego u Hrvatskoj:16

Plaća tamo dolazi svaki tjedan, svaki četvrtak u 7-8 ujutro ja znam da meni sjeda plaća. (Laura, r. 1988., povjesničarka, radi kao sobarica)

Kao privlačne faktore za useljavanje $u$ Irsku naši su kazivači isticali i engleski jezik, kojim većina, pogotovo mladih, u Hrvatskoj dobro vlada. Također, za život i posao dovoljno je podnijeti zahtjev za PPS, iskaznicu koja je ujedno i osobna i zdravstvena. Nakon toga potrebno je otvoriti bankovni račun, za koji je potrebna kućna adresa. Imigranti kao mjesto boravka mogu prijaviti adresu hostela u kojem su smješteni. Svoje iskustvo opisala nam je ista kazivačica:

Sustav je vrlo jednostavan, dogovori se termin za taj PPS broj i on je za par dana

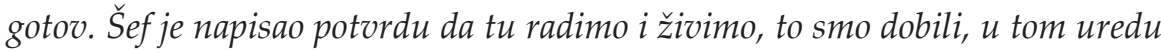
smo bili gotovi za $10 \mathrm{~min}$, u banci za pola sata $i$ sve je bilo gotovo... porez, vrlo jednostavno... nismo trebali niš sami sad bauljat okolo po Irskoj i tražit. Na taj PPS sve ide plaća, mirovinsko, zdravstveno, porez, sve vrlo jednostavno, kaj god smo trebali samo tu karticu pokažeš. (Laura, r. 1988.)

Na internetskoj stranici agencije za zapošljavanje čija je suvlasnica kazivačica A. Vukina Stojanović kao razlozi zbog kojih treba odabrati Irsku za život i rad ukratko su navedene sljedeće prednosti: Irska je prva po brzini

15 https://www.welfare.ie/en/Pages/Personal-Public-Service-Number-Statistics-on-Numbers-Issued.aspx

16 U budućim bi se istraživanjima trebalo obuhvatiti migrante različitih obrazovnih profila zaposlenih u svojoj struci i izvan nje. Prema kazivačici A. Vukina Stojanović, koja je vlasnica posredničke agencije, u Irsku migrira određeni broj informatičkih stručnjaka koji rade u struci, a podaci iz Hrvatske liječničke komore (za razdoblje od 1. siječnja 2013. do 31. kolovoza 2016.) govore da je Irska treće odredište (iza Velike Britanije i Njemačke) u koje odlazi 9\% hrvatskih liječnika i drugoga medicinskog osoblja (Župarić-Iljić, 2016: 9). 
ekonomskog rasta u eurozoni u 2015.; Irska je u lipnju 2014. izvozila 6\% više negoli u istom razdoblju 2013.; Irska ima najviša strana ulaganja po stanovniku u Europi; Irska je drugi najveći izvoznik softvera na svijetu; Irska je među najjačim izvoznicima farmaceutskih proizvoda na svijetu $(28 \%$ od ukupnog izvoza); Irska ima najveći broj zaposlenih u hightech-sektoru u Europi. ${ }^{17}$

\section{MEZOKONTEKST ISELJAVANJA}

Osim makroekonomskoga i makropolitičkoga konteksta migracijskog procesa u ovom se istraživanju iznimno bitnom pokazala i mezostruktura. Riječ je o području između marko- i mikrostrukture koje čine razni akteri »industrije migracija « koji danas imaju važnu ulogu u posredovanju migracija (usp. Castles i Miller, 2003: 134-135; Bretell i Hollifield, 2000). Trenutačno postoje mnogi posrednici pri migriranju iz Hrvatske u Irsku koji nude posredničke usluge (privatne agencije za zapošljavanje iz Irske, EURES - Europski portal za mobilnost pri zapošljavanju ${ }^{18}$ ) ili su informacije dostupne preko društvenih mreža i blogova.

Kao primjer posrednika u migraciji ovdje će biti ukratko predstavljeno djelovanje agencije za regrutiranje/zapošljavanje - Irish Recruiter. Agencija je osnovana nakon ulaska Hrvatske u EU, ima sjedište u Dublinu i omogućuje irskim agencijama i tvrtkama traženje IT-stručnjaka za rad u Irskoj, a kandidatima iz Hrvatske prijavu za radna mjesta u Irskoj uz besplatnu podršku pri zapošljavanju. Irish Recruiter dobiva proviziju od poslodavca ili agencije za zapošljavanje za svakoga uspješnoga kandidata tek kada kandidat prođe probni rok na novom poslu. ${ }^{19}$ Suvlasnica A. Vukina Stojanović o funkciji agencije koju vodi sa suprugom kazala je:

Mi zapošljavamo vrhunske stručnjake za jako specifične poslove. Tortke nas nazovu i [...] pitaju da im pronađemo ljude. Mi ćemo prije naći ljude nego oni nas. Jer to nisu ljudi koji nemaju posla, nego su to ljudi koji su i u Hrvatskoj jako dobro plaćeni. To nije ekonomska emigracija, nego potreba $i$ želja da se nauči nešto novo, brže napreduje, itd. (A. Vukina Stojanović, Irish Recruiter)

Osim informacija vezanih uz zaposlenje na svojim službenim stranicama agencija Irish Recruiter nudi i podršku u razdoblju preseljenja pružajući do-

17 http://www.irishrecruiter.com/zivot-u-irskoj/

18 EURES - Europski portal za mobilnost pri zapošljavanju funkcionira preko Hrvatskog zavoda za zapošljavanje i njihova Ureda za europske poslove, https://ec.europa.eu/eures/ public/hr/homepage.

19 http://www.irishrecruiter.com/o-nama/ 
datne praktične informacije vezane uz život u Irskoj, poput onih o stanovanju, osiguranjima, bolnicama, javnom prijevozu itd. Riječ je o višestrukom programu posredovanja u migraciji, što putem usluge nalaženja poslodavca, što davanjem informacija o novoj sredini radi lakše prilagodbe.

Još jedan primjer posredovanja agencije za zapošljavanje odnosi se na oglas na hrvatskome internetskom portalu moj-posao.net: »Noel Recruitment Ireland (14. rujna 2015.) agencija za zapošljavanje u Irskoj, u suradnji s tvrtkom Musgrave Retail Partners Ireland, najvećom logističkom i distribucijskom tvrtkom u Irskoj, došla je u Hrvatsku s ciljem pronalaska radnika sa skladišnim i logističkim iskustvom koji su voljni otići raditi u Irsku. «20 $\mathrm{U}$ jednome zagrebačkom hotelu dva su se dana intervjuirali potencijalni zaposlenici.

Vlastita iskustva o tome kako funkcionira EURES (Europski portal za mobilnost pri zapošljavanju) opisala je jedna kazivačica:

...odlučili [smo] ajmo prevesti životopise na engleski, poslati, pa budemo vidjeli kak će bit, nismo poslali 5-6 e-mailova, ne više. To smo slali preko EURES-a. Onda sam ja zvala ženu u HZZ [...] iz Ureda za europske poslove [...] rekla nam je koji papiri nam trebaju, kaj da napravimo, koji je postupak... U roku tjedan dana meni se ta žena iz hotela [iz Irske] javila jesmo zainteresirani hoćemo ići raditi? Ja pitam jel može $i$ dečko? Jel smo mi zajedno poslali prijave al valjda njegovu nije vidla, kaže kak da ne ima još pozicija. Mi kažemo može i dala nam je tri tjedna da se spremimo i dođemo. To je bilo to... (Laura, r. 1988.)

Zanimljiva je pojava još jednog posrednika u migracijskim procesima. Osnivanjem udruge OSMATIZO - Osječka matica iseljenih i zaposlenih Osječana u inozemstvu - krajem 2014. stvoren je izravni posrednik između dviju zemalja, porijekla i useljenja. ${ }^{21}$ Njeno je djelovanje usmjereno na pružanje usluga migrantima u području iz kojeg se emigriralo kako bi svojim inozemnim članovima, a veliki broj njih nalazi se i u Irskoj, pružala različite usluge: pribavljanje dokumenata, obilazak grobova u njihovo ime ili posjećivanje obiteljskih svečanosti, dok članovima iz Hrvatske osigurava lakše kontakte s inozemstvom. Postojanje takve udruge kao specifičnog posrednika upućuje na intenziviranje transnacionalnog načina života migranata. Također, njezina pojava i potreba za njezinim uslugama dokazuju intenzitet migracija i brojnost migranata s područja Osijeka i šire okolice.

Sljedeći primjer mezostrukture ne možemo definirati kao konkretno tijelo, agenciju ili udrugu u posredovanju jer je riječ o društvenoj platformi kao

20 http://www.moj-posao.net/Vijest/75255/Za-sve-koji-zele-raditi-u-Irskoj/2/

${ }_{21}$ http://www.udrugaosmatizo.hr/index.php/home 
posredniku. Posrijedi je grupa »Idemo u Irsku« na Facebooku koja istovremeno čini i virtualni zbroj raznih mikrokonteksta, odnosno brojnih iskustava pojedinaca. No sagledamo li njezinu funkciju u virtualnoj sferi ne samo u razmjeni informacija nego i u omogućivanju raznih dogovora i usluga, njezina je uloga posrednika unutar velike mreže ljudi neosporna. U usporedbi s drugim grupama koje okupljaju članove na temu migriranja u Irsku i života u njoj, ${ }^{22}$ grupa »Idemo u Irsku « trenutačno ima najviše članova te se njihov broj povećava (19.480 članova 2015., 40.804 članova 2017.). Riječ je o važnoj karakteristici globalnih migracijskih procesa, gdje je »revolucija u komunikaciji postala centralnim elementom « (Koser, 2007: 33). Khalid Koser (2007: 36) smatra da današnje migracije oblikuju migrantske mreže, što putem analize sadržaja gore navedene grupe možemo potkrijepiti primjerima u dva smjera - pružanja informacija i pružanja pomoći pri dolasku, tj. nalaženja posla, smještaja itd. Ta grupa na Facebooku, kako kažu iseljenici, primarni je izvor informacija za potencijalne migrante u Irsku. Nudi informacije o Irskoj, poveznice s drugim stranicama i platformama, praktične informacije o pripremi za preseljenje i nalaženje posla te razne detalje o životu ondje. Mnogi članovi ovim se putem povezuju, pronalaze suputnike, cimere i smještaj itd. Također, mnogi postovi odnose se na pozive za druženja i okupljanje članova uživo. U grupi postoji posebni dio gdje svi mogu objavljivati i čitati razne oglase u Irskoj (prodajem/kupujem/mijenjam/prevozim/dijelim...). Neki se članovi raspituju o novom društvu i mentalitetu, primjerice tražeći mišljenje drugih postoje li nesnošljivost i diskriminacija prema strancima te kako se oni općenito doživljavaju u društvu. Svakodnevno se objavljuje po nekoliko desetaka različitih postova s informacijama ili pitanjima. ${ }^{23}$

\section{PRIPREME ZA PRESELJENJE I PLANIRANJE PRESELJENJA}

Prikupljanje informacija putem interneta bilo je početni čin pripreme za migraciju i život u novoj sredini gotovo svih naših informanata. Riječ je o prikupljanju kulturnoga kapitala, odnosno znanja o drugoj državi te

22 Opis grupe je: »Grupa za sve sa područja ex-yugoslavije koji žele više inf. o Irskoj te podjelit iste« (https://www.facebook.com/groups/idemouirsku/). Uz nju postoje još i grupe »Idemo u Dublin«, »Hrvati u Dublinu«, »Hrvati u Corku«, »Hrvati u Galwayu« itd.

23 Specifična su vrsta izvještavanja o vlastitom iskustvu i širenja informacija i blogovi. Tijekom istraživanja pronađeno ih je nekoliko, npr. »Život u Dublinu«, »Dublin efekt«, »Igor Stojaković« (uključuje i kategoriju »Life in Ireland«). Blogovi su također zanimljiva građa za buduća istraživanja jer autori migranti detaljno iznose vlastita mišljenja i iskustva. Dublja analiza tih sadržaja premašila bi okvire ovoga rada. 
mogućnostima putovanja, zaposlenja i prilagodbe novoj sredini (usp. Grbić Jakopović, 2014: 28). Ideja preseljenja u Irsku uglavnom se pojavila kod kazivača zbog sličnih primjera iz neposredne okoline, izravnim kontaktom s osobom koja se već iselila, te zbog priča koje su čuli od prijatelja, sugrađana, poznanika i medija. Želeći istražiti načine na koje su se pripremali za odlazak, kazivače smo pitale koliko je dugo trajala priprema te gdje su, kako i od koga prikupljali informacije:

Dva tjedna sam se pripremao. Ništa, malo pročito, pogledo na stranici jobs.ie. (Neven, r. 1989., mag. ekonomije, smjer turistički menadžment, radi u prodaji u lancu brze hrane)

Nikako, čitao sam malo po grupi »Idemo u Irsku«... (Marko, r. 1992., prodavač-komercijalist, radi u restoranu)

Nešto temeljitiju pripremu za odlazak proveo je Ivan, koji je uz istu grupu na Facebooku informacije prikupljao od prijateljevih poznanika u Irskoj. Navedenu grupu istaknuo je kao velik problem:

Dolaze ljudi ovdje i tako olako sve ovo shvaćaju, a za to sve je kriva grupa »Idemo u Irsku«. Ja sam 70\% toga napravio bez te grupe. (Ivan, r. 1994., upravni referent, radi u supermarketu)

I druge dvije imigrantice kombinirale su prikupljanje informacija putem interneta te od poznanika i prijatelja:

Moja priprema za odlazak je trajala par mjeseci. Prvo sam se prijavila na sve stranice na internetu i grupe na Facebooku koje imaju veze sa Irskom (kultura, običaji, klima, narod, što je sve potrebno za odlazak, kakva je financijska situacija, da li ima posla, što se nudi, $i$ sl.). Osim putem interneta, informirala sam se naravno i preko poznanika. (Ivona, r. 1990., viša stručna sprema, smjer trgovina, radi u prodaji u McDonaldsu)

Priprema nije dugo trajala, možda sveukupno mjesec dana. Kupila sam kartu mjesec dana prije dolaska jer je tako bila jeftinija, imam jednu prijateljicu s faksa koja živi u Corku s kojom sam se čula tijekom priprema $i$ ispitivala sam je o svemu: kako je u Irskoj, Dublinu, Corku, kakvi su uvjeti za rad, gdje se može najprije dobiti posao, kakvi poslovi su traženi itd. Upoznala sam još jednog dečka preko Facebooka, inače je iz Orahovice, on mi je pomogao oko svega savjetima i praktično kada sam došla u Dublin. Nisam prethodno našla niti posao, niti smještaj, sve nakon dolaska. (Kristina, r. 1984., informatologinja, pola radnog vremena radi u McDonaldsu u prodaji, pola u trgovini)

Iz posljednjega iskustva vidljivo je da društvene mreže služe za informacije i sklapanje poznanstava te iz virtualne sfere prelaze $u$ prijateljstva 
$\mathrm{u}$ »stvarnom « svijetu i konkretnu pomoć prilikom dolaska u imigracijsko odredište.

Nakon odluke da će zajedno otići raditi te razmatranja kamo, za odabir Irske kod jednog su para presudili znanje engleskog jezika i pozitivna iskustva drugih imigranata:

Prvo je to počelo on ima rodbinu u Njemačkoj pa ajmo tamo, klasična priča imaš nekog... al ja nisam znala njemački pa sam uz njega počela učiti... To smo počeli planirati prošle godine za Božić, onda on meni za tri dana javi: Znaš svi živi idu u Irsku, pa znamo jezik, puno ljudi odavde je ošlo tamo i za tri dana našlo posao $i$ tak ajmo probat, ajmo ovak, ajmo onak. Nismo imali novca pa smo odlučili idemo prou godinu na more radit pa s tim zaradenim novcem idemo van. Onda smo ipak odlučili ajmo prevesti životopise na engleski... (Laura, r. 1988.)

$\mathrm{Na}$ temelju iznesenih iskustava možemo zaključiti da su se migranti obuhvaćeni ovim radom relativno kratko pripremali za migraciju, od dva tjedna do nekoliko mjeseci. Iskustva iseljenika dokazuju današnje migracijske pogodnosti, odnosno brže i jeftinije putovanje na daleke destinacije te ključnu ulogu sveprisutne globalne komunikacije (usp. Lewellen, 2002: 125, 126). Da je riječ o suvremenom obilježju migracija, svjedoči potpuno drugačije iskustvo kazivačice koja je migrirala u Dublin 1998.:

U ono doba internet nije bio u današnjoj formi, informacija nikakvih nije bilo, naših ljudi nije bilo. Bio je to jedan kalkulirani rizik. Nije bilo društvenih mreža ni stranica. Prošli smo sve kroz vlastito iskustvo i sve smo morali proći sami zajedno s Ircima i drugim strancima. Ja sam sve informacije dobila kroz poznanstva. (A. Vukina Stojanović, Irish Recruiter)

Ista kazivačica, A. Vukina Stojanović, istaknula je problem današnjeg informiranja osoba koje žele emigrirati u Irsku, kao i pravilan i jednostavan način koji je moguć svima s dovoljno volje:

Mnogi će informacije dobit od ljudi koji su tek nedavno došli, i tamo su mjesecdva, a ne od nas koji smo tamo već dugo, dugo godina. Nedovoljno su pripremljeni, a opet, danas su informacije jako dostupne. Dosta informacija na društvenim mrežama nije sasvim točno, nečija osobna iskustva ne vrijede kao opće pravilo. Irci koji su već primili jako puno stranaca imaju i dobre stranice upravo za informiranje, npr. taj Citizen informations di piše sve od toga kako preseliti psa i mačku do toga kako se obračunavaju porezi, itd. (A. Vukina Stojanović, Irish Recruiter)

U usporedbi s njezinim iskustvom očito je da današnje mogućnosti olakšavaju preseljenje. Dvoje kazivača potvrdilo je već spomenutu negativnu stranu globalnih informacijskih platformi koje šire zbunjujuće slike o mi- 
gracijskoj realnosti i dezinformacije. Svjesna toga, većina kazivača usporedila je te izvore s iskustvima osoba koje su već emigrirale. Upravo je povezivanje s osobama koje su već emigrirale, odnosno socijalne migrantske mreže, specifično svojstvo ovoga migracijskog vala. Prethodno je u radu navedeno kako je riječ o zaista velikom broju mladih ljudi koji emigriraju u Irsku s područja Slavonije, stoga ne čudi da gotovo svi iseljenici koje smo obuhvatile istraživanjem imaju poznanike koji su se već iselili.

\section{POTISNI (PUSH) FAKTORI ISELJAVANJA}

Migracije se općenito mogu promatrati kao odgovori na razlike između dvaju prostora, u ovom slučaju država. Među razlikama koje mogu biti ekonomske i neekonomske prirode nalaze se razine oblikovane potisnim (push) i privlačnim (pull) faktorima koje međusobno povezuje ključni, mrežni faktor (usp. Martin, Abella i Kruptsch, 2006: 7). Kako bismo utvrdile uzroke migracije istraživane skupine, iseljenicima su postavljena pitanja kada su i zašto počeli razmišljati o iseljenju iz Hrvatske. Time smo nastojale doznati potisne (push) faktore, s ciljem tipologizacije uzroka migracija:

O odlasku iz Hrvatske sam počela razmišljati prije dvije, tri godine kada sam završavala fakultet. Znala sam da poslije fakulteta neću uspjeti naći posao - konobarenje ne računam, pa sam počela istraživati koja bi mi opcija bila najbolja i šta mi je sve potrebno kako bih otišla u drugu državu. U Irsku sam otišla 29. 4. 2015. i planiram ostati što duže tj. ne planiram se vraćati u Hrvatsku. (Ivona, r. 1990., viša stručna sprema, smjer trgovina, radi u McDonaldsu)

Kod nekih se kazivača razmišljanje o iseljavanju nametnulo kao posljedica političkog nepotizma i psihološkog nezadovoljstva:

Otišao sam 6. 3. 2014. godine. Počeo sam razmišljati šest mjeseci prije, jednostavno sam pukao kad sam vidio da za sve što hoću napraviti ovdje moram imat vezu. (Marko, r. 1992., prodavač-komercijalist)

Naša divna Slavonija propada već godinama te sam ja jako rano morao napustiti svoj dom i sa 17 godina sam počeo radit sezone [na Jadranu] [...] Nakon diplome se vraćam doma u Našice i radim kao trgovac i kasnije kao konobar te nakon uzaludnog slanja mailova za pripravnički ili bolji posao - bez pretjerivanja sam poslao preko 1000 mailova $i$ zamolbi za kojekakve natječaje, nisam imao veze ni političke, a ni rodbinske za bolji posao, pa sam odlučio ako moram radit takve uslužne poslove, onda ću ih radije radit negdje za normalan novac i normalan život. (Neven, r. 1989., mag. ekonomije, smjer turistički menadžment) 
Kod jedne je kazivačice osim ekonomskog motiva presudnu ulogu odigrala znatiželja:

Ja cijeli život razmišljam o odlasku iz Hrvatske jer me jako zanimaju strane zemlje, stranci, njihove kulture i običaji, putovanja i kada mi se [...] pružila prilika, samo sam se spremila i otišla. Glavni motiv bio mi je otići iz Hroatske, putovati i usput naći zaposlenje... Emigrirala sam nakon možda jedno dvije godine intenzionog razmišljanja o odlasku. U Irsku sam došla 20. 1. 2015. (Kristina, r. 1984., informatologinja)

Kao jedan od potisnih razloga navedeno je i hrvatsko konzervativno društvo:

Zato što kao osobi koja je u istospolnoj vezi negdje mogu živjeti slobodnije i prihvaćenije. I što sa svojim kvalitetama, iskustvom i znanjem, negdje mogu imati puno kvalitetniji život. (Marija, r. 1983., psihologinja i odgajateljica, radi u trgovini)

Ispitanica i ispitanik, par iz različitih hrvatskih mjesta porijekla, koji su zajedno studirali povijest i bili u vezi tijekom školovanja u Zagrebu, nakon završetka studija vratili su se svatko svojim roditeljima. Nakon dvije godine veze na daljinu, završenog stručnog osposobljavanja i povremenih poslova u svojim rodnim mjestima odlazak su vidjeli kao jedini način da počnu zajedno stanovati i raditi:

Da živimo zajedno i radimo, bilo je to definitiono. Ja sam još nekak sebe mogla u svom gradu ubacit, ali još i njega koji je Slavonac $i$ koga niko po prezimenu ne zna, a u tim malim gradovima to je mafija. Ja kad idem s tatom i kad mi vide prezime odmah sam na redu, a kad ne vide prezime i kad sam sama stojim tam [pred nekim šalterom], to je grozno. Tak da znam ako bi i uspjela negdje sebe ubacit [zaposliti] njega neću. Kaj se sada dešava, roditelji vuku djecu već iz vrtića $i$ iseljavaju, a kad dođu u školu još ih je manje, ima sve manje djece i razredi se gase, a kad zadnji dođeš u školu proi odlaziš [gubiš posao]. (Laura, r. 1988.)

Njezin tadašnji dečko, sada suprug, dodao je:

Ja vjerujem da bi se mi mogli [zaposliti] svatko na svom području, ići na zamjene, imati po pola satnice i tako preživljavanje ali koliko bi to trajalo. Jer ja znam ova moja osnovna škola u koju sam ja išao i u kojoj jesam kratko radio, jer imam godinu dana radnog staža, imali su 1998. A, B, C razred. Ove godine [2016.] su upisali samo jedno odjeljenje i to možda 15 učenika. Zašto nitko ništa o tome ne piše? Kako može škola izgubiti toliko đaka?... (Dario, r. 1988.)

Kao što pokazuju kazivanja, za većinu sugovornika glavni motiv za odlazak bio je ekonomske prirode (nemogućnost nalaženja zaposlenja u stru- 
ci, rješavanje stambenog pitanja i zajedničkog života mladog para), no u kombinaciji s drugim razlozima. Istaknule bismo psihološke razloge uzrokovane političkom korupcijom i nepotizmom. Kod Marka i Nevena jasno se prepoznaje negativan, gotovo ogorčen ton kada govore o razlozima odlaska. Zbog velike nezaposlenosti koja ih okružuje neki su kazivači već tijekom školovanja počeli razmišljati o odlasku. Iz prikupljene građe vidimo da postoje i brojni drugi razlozi: želja za životom u liberalnijoj sredini, znatiželja (upoznavanje novih kultura i naroda) te profesionalno usavršavanje, koje vežemo uz migracije »odljeva mozgova «. ${ }^{24}$ Imigrantica Ana je nakon studija u Osijeku te doktorskog studija u Kanadi odabrala Irsku kao poticajnu sredinu za stvaranje karijere.

Kazivačica A. Vukina Stojanović emigrirala je krajem prošlog stoljeća iz obiteljskih razloga, tj. prateći supruga, kojeg je strana informatička kompanija zaposlila u Dublinu. Njihova odluka bila je svjestan odabir: suprugovo profesionalno usavršavanje. Sustavna istraživanja tek bi trebala potvrditi je li odlazak visokoobrazovanih ( $\mathrm{zv}$. odljev mozgova) prevladavao u individualnim migracijama iz Hrvatske u Irsku prije njezina ulaska u EU i otvaranja tržišta rada. Budući da dvadesetak godina živi u Irskoj, gdje se druži s drugim iseljenicima iz Hrvatske te da radi u agenciji za zapošljavanje Hrvata u Irskoj, objasnila je kompleksnost razloga iseljavanja:

Razlozi zbog kojih ljudi emigriraju i zašto to na kraju ispadne Irska su jako, jako različiti. Neki jesu ekonomski, ljudi nemaju posla, plaće, pa su jednostavno prisiljeni. Drugi razlozi su jednostavno da ljudi žele proširit horizonte i probati nešto drugačije. Neki žele nepredovat u struci, ali to ne mogu u onoj radnoj sredini u kojoj jesu pa žele iskusit nešto novo... sve jako varira. (A. Vukina Stojanović, Irish Recruiter)

Stoga, jednostranu ekonomsku sliku razloga iseljavanja mladih iz $\mathrm{Hr}-$ vatske, odnosno Slavonije u Irsku, na kojoj se temelji javni diskurs, valja tumačiti oprezno. Iako je zaista velikom broju ljudi iz Slavonije iseljenje posljednje moguće rješenje za »normalan « život, kod nekih je riječ o svjesnom odabiru, različitim i višestrukim pokretačima migracijskog procesa.

24 Većina je kazivača visokoobrazovana i po tom kriteriju spadaju u kategoriju odljeva mozgova, no primarni razlog migracije nije bio profesionalno usavršavanje. 


\section{PRIVLAČNI (PULL) FAKTORI}

Osim razloga odluke da se isele iz Hrvatske željele smo saznati zašto su iseljenici odabrali Irsku kao odredište. Jesu li razmišljali i o drugim državama kao sredinama za novi početak? Odgovori su bili različiti:

Iskreno, ne znam, nama Balkancima oduvijek je raj bila Njemačka jel, zašto Irska, još uvijek mi nije jasno, valjda samo da se maknem iz Hrvatske, nebitno gdje. (Marko, r. 1992., prodavač-komercijalist)

Irska je u tome trenutku bila jaka tema, kada se pričalo gdje otići van Hrvatske. (Ivan, r. 1994., upravni referent)

Preko Facebooka sam čula o velikom broju ljudi koji odlaze u Irsku i počela istraživati mogućnosti. Irska je ispala najjednostavnija opcija [birokratski], blizu je domu, i nakon što sam malo putovala je činjenica da ostajem u Europi postala prilično važna. (Ana, r. 1982., dr. sc. književnosti i kulture, radi u Appleu)

Neki su kazivači razmatrali različite države engleskoga govornog područja zato što taj jezik dobro govore:

Da, razmišljala sam i o drugim državama. Prije godinu dana sam počela istraživati Australiju i dosta mi je to oduzelo vremena. Nije baš lako otići dolje jer treba puno novaca dok se izganjaju papiri, plati karta, polože tečajevi i sl., a još uz sve to treba imati dosta novaca na računu. Nakon nje sam se odlučila za Irsku zbog jezika, a iz zbog nje same. Oduvijek sam htjela posjetiti Irsku i nikada mi neće biti žao jer sam oduševljena. Engleski znam super, pa eto, smatrala sam da mi je to odmah velika prednost. (Ivona, r. 1990., viša stručna sprema, smjer trgovina)

...i tako sam pričao sa susjedom oko te Kanade, i on mi je reko da mu je prijatelj u Irskoj, da se dobije PPS broj na osobnu bez problema i da se može nać posla lako, i tako smo se mi u dva tjedna sve dogovorili, organizirali i utekli. (Neven, r. 1989., mag. ekonomije, smjer turistički menadžment)

Iz prikazanih iskustava saznajemo da je za neke kazivače Irska bila prvi odabir zbog aktualnosti, sveprisutnosti te teme $u$ javnim i privatnim sferama, preporuke prijatelja i pozitivnih iskustva prijašnjih migranata, a za druge je ona bila logična odluka u razmatranju više opcija. Osim Irske kazivači su razmišljali o odlasku u Njemačku, Kanadu i Australiju. Kao ključne razloge za odlazak onamo, Irsku su istaknuli kao privlačno odredište zbog engleskog jezika koji znaju, otvorenog tržišta rada, jednostavnih birokracijskih procedura potrebnih za rad i život te dobre prometne povezanosti, odnosno relativne blizine (u odnosu na Ameriku i Australiju). Za većinu je 
ključna bila mogućnost brzog nalaženja posla jer su bili nezaposleni. No osim mogućnosti zapošljavanja neki su kazivači istaknuli i privlačnosti države kao turističke destinacije koju su ionako željeli posjetiti. Bez jasnih razloga izdvaja se samo kazivač Marko, koji je naglasio sâm odlazak iz Hrvatske kao jedinu bitnu stavku, a odredište mu je bilo sporedno.

\section{ZAKLJUČAK}

U okviru suvremenih vanjskih migracija stanovnika Hrvatske posljednjih se godina pojavio trend iseljenja u Republiku Irsku. Iako je u Irskoj i prije ulaska Hrvatske u EU živio manji broj hrvatskih građana, tek od 2013. možemo pratiti intenzivnija useljavanja. Razlog tomu jest otvaranje irskog tržišta rada stanovnicima Hrvatske, koji su se, suočeni s velikom stopom nezaposlenosti, posebice unutar mlađe populacije, odlučili iseliti u potrazi za boljim životnim uvjetima. Upravo je činjenica da najviše iseljavaju mladi, uz nezaposlenost je jedna od važnijih odrednica suvremenih migracija. Većina migranata koje smo kontaktirale za potrebe ovoga rada porijeklom je iz Slavonije, regije u kojoj se nalaze tri županije s najvišim brojem vanjskih migranata. Razloge tog migracijskog vala promatrale smo kao rezultat djelovanja potisnih faktora, kojih u trenutačnim uvjetima za život $\mathrm{u}$, kako su naši sugovornici objasnili, »zanemarenoj, gospodarski nerazvijenoj, korumpiranoj i pokradenoj regiji« Slavoniji ne nedostaje, te privlačnih faktora koje posjeduje Irska zahvaljujući gospodarskom oporavku, ubrzanom razvoju, jednostavnoj birokratskoj proceduri za ulazak na tržište rada, engleskom jeziku koji iseljenici koje smo kontaktirali govore itd. Da je za suvremene migrante tržište rada samo poticaj, potvrđuju iskustva kazivača. Iako prevladavaju ekonomski čimbenici migracija, mnogi migranti iznijeli su i druge razloge za odlazak: osobna psihološka nezadovoljstva potaknuta nepotizmom i korumpiranosti od lokalne do nacionale razine, neuvažavanje ljudskih prava odnosno konzervativna sredina, znatiželja itd. Osim makrokonteksta kroz koji smo promatrale ovaj suvremeni val iznimno je važan i mikrokontekst, posebice umreženost migranata, tj. socijalne migrantske mreže. Naime mnogi su se odselili uz pomoć prethodnih migranata ili zajedno s drugima iz Slavonije, a osim toga upravo su iskustva prethodnih migranata smatrali najvjerodostojnijim informacijama. Tijekom istraživanja bitnom se pokazala uloga suvremene komunikacijske tehnologije u generiranju, prenošenju i razmjeni znanja povezanih članova migracijskog procesa, što izravno dokazuje funkcioniranje virtualnih umreženja, poput onoga u grupi »Idemo u Irsku« na Facebooku. Danas su migranti informirani više nego ikada prije 
zahvaljujući upravo virtualnim društvenim mrežama, tj. globalnim platformama za umrežavanje. Uz njih je usko vezana uloga posrednika koji tvore mezostrukture te povezuju i olakšavaju migracije. Osim navedene grupe na Facebooku, koja 2017. godine okuplja 40.804 članova (2015. broj je bio upola manji), uloga posrednika vidljiva je na primjeru agencija za zapošljavanje Irish Recruiter iz Dublina i EURES-a i udruge OSMATIZO iz Osijeka.

U radu je prikazana etnografija pojedinačnoga s ciljem prikaza iskustava deset iseljenika i namjera nije bila generalizirati. No uočena su određena obilježja ovoga recentnog migracijskog vala. Od 2014. riječ je o prevladavajućim vanjskim i dobrovoljnim migracijama mladih uglavnom visokoobrazovanih ljudi koji tečno govore engleski jezik, no koji su, barem u početku, spremni raditi poslove daleko ispod svoje kvalifikacije. Ovo istraživanje pokazuje da se »velik broj hrvatskih migranata [...] zapošljava u zanimanjima za koja su prekvalificirani, što se obično opisuje kao 'brain-waste', odnosno gubitak ili traćenje mozgova « (Božić, 2014: 294). Dakako da je svaki takav visokoobrazovani migrant »veliki gubitak za zemlju emigracije« (Božić, 2014: 294). Iako tek treba provesti sustavna istraživanja razloga iseljavanja hrvatskih građana u Irsku prije 2013., odnosno ulaska Hrvatske u EU, prema informacijama migrantice koja ondje živi dvadesetak godina, sklone smo pretpostaviti da je riječ također o visokoobrazovanim migrantima, no koji su najvjerojatnije dobili posao u struci.

Ovaj recentni migracijski val moguće je dalje istraživati na više razina. Budući da se sada odvija putem suvremenih tehnologija, možemo steći izravni uvid u mnoga njegova obilježja i na razini pojedinačnih iskustava.

Iako su statistički podaci tek polazište za etnološka i kulturnoantropološka kvalitativna istraživanja, ovaj rad pokazao je njihovu ogromnu neusklađenost. Za razliku od Hrvatske, države iseljenja, koja ima jako manjkave podatke i u čije je statistike Irska uvrštena tek 2016. godine, Irska, zemlja useljenja, ima detaljne podatke o broju stranaca koji su ušli na tržište rada (no ne i o tome jesu li ondje ostali trajno).

Neovisno o statistikama i brojevima, prema kojima jedino možemo zaključiti da mnogo, posebice mladih, odlazi možda i trajno iz domovine u potrazi za boljim ili, kako kažu, »normalnim« životom, to uvijek najteže prihvaćaju njihovi roditelji:

Našim mamama je najgore. Nisu očekivale da ćemo morati otići jer ipak su oni nekak uz srednje škole nas uspjeli podići i osigurati nam fakultetsko obrazovanje. Stalno su nam govorili samo vi diplomirajte lako ćete onda! (Laura, r. 1988.)

Tijekom istraživanja uočile smo i manipulacije medija i/ili političkih eli- 
ta stvarnim statističkim podacima o suvremenom iseljavanju iz Republike Hrvatske. Primjerice Državni zavod za statistiku iznio je pozitivne podatke o smanjenju nezaposlenosti - u siječnju 2014. iznosila je 22,3\%, a u siječnju 2017. 15,4\%. ${ }^{25}$ Nažalost, čini nam se da je to velikim dijelom rezultati iseljavanja, što se lako sazna kada se usporedi broj zaposlenih, koji se ne povećava takvim intenzitetom. Osim toga svi iseljenici koje smo kontaktirali za potrebe ovoga istraživanja, a koji su prije odlaska bili registrirani na Hrvatskom zavodu za zapošljavanje, prije odlaska morali su se odjaviti. Prilikom odlaska službenici su samo jednu djevojku upitali za razlog odjave. Prema prikupljenim podacima koji su predstavljeni u radu, možemo samo pretpostaviti da će doći do još većeg »smanjenja nezaposlenosti« u Slavoniji i ostatku države.

\section{LITERATURA}

Akrap, A. (2014). Promjene broja i prostornog razmještaja stanovništva Hrvatske i županija, u: V. Puljiz, J. Tica i D. Vidović (ur.). Migracije i razvoj Hrvatske: Podloga za hrvatsku migracijsku strategiju. Zagreb: Hrvatska gospodarska komora, 25-71.

Apaduraj, A. [Appadurai, A.] (2011). Kultura i globalizacija. Beograd: XX vek.

Božić, S. (2014). Hrvatska migracijska politika: od skice do strategije, u: V. Puljiz, J. Tica i D. Vidović (ur.). Migracije i razvoj Hrvatske: Podloga za hrvatsku migracijsku strategiju. Zagreb: Hrvatska gospodarska komora, 285-300.

Brettel, C. i Hollifield, J. F. (2000). Migration Theory: Talking Across the Disciplines. New York - London: Routledge.

Castles, S. i Miller, M. J. (2003). The Age of Migration: International Population Movements in the Modern World. New York - London: Guilford Press.

Fanning, R., Boland, F.H., Kay, S., O’Beirne Ranelagh, J., i Edwards, R.W.D. (2017). Ireland: Economy, in: Encyclopædia Britannica. https://www.britannica.com/place/ Ireland/Economy (20. lipnja 2017.).

Filipović, M. (2015). Nezaustavljiv egzodus s Balkana, Balkans.aljazeera.net, 13. svibnja. 2015, http://balkans.aljazeera.net/vijesti/nezaustavljivi-egzodus-s-balkana (1. rujna 2015.).

Grbić Jakopović, J. (2014). Multipliciranje zavičaja i domovina. Hrvatska dijaspora: kronologija, destinacije $i$ identitet. Zagreb: FF-press.

Grizelj, M. i Akrap A. (2011). Projekcije stanovništva Republike Hrvatske od 2010. do 2061. Zagreb: Državni zavod za statistiku.

Koser, K. (2007). International Migration: A Very Short Introduction. Oxford, New York: Oxford University Press, doi:https://doi.org/10.1093/actrade/9780199298013.001.0001

Legrand, C. (2005). Nation, migration and identities in late twentieth-century Ireland, Narodna umjetnost: hrvatski časopis za etnologiju i folkloristiku, 42 (1): 47-63.

25 www.dzs.hr. 
Lewellen, T. C. (2002). The Anthropology of Globalization: Cultural Anthropology Enters the 21st Century. London: Bergin \& Garvey.

Martin, P., Abella, M. i Kuptsch, K. (2006). Managing Labor Migration in TwentyFirst Century. London: Yale University Press, doi: https://doi.org/10.12987/ yale/9780300109047.001.0001

Pleše, I. (2006). Jesam li bila na terenu, u: J. Čapo Žmegač, V. Gulin Zrnić i G. P. Šantek (ur.). Etnologija bliskoga. Poetika i politika suvremenih terenskih istraživanja. Zagreb: Institut za etnologiju i folkloristiku - Jesenski i Turk, 117-139.

Potkonjak, S. (2014). Teren za etnologe početnike. Zagreb: HED biblioteka - FF-press.

Rančić, N., Rebac L. i Pilipović, O. (2010). Izazovi i pouke irskog gosporadskog razvoja, Pravnik: časopis za pravna i društvena pitanja, 44 (88): 21-50.

Smyth J. W. (2011). Ireland and Northern Ireland, u: K. J. Bade, P. C. Emmer, L. Lucassen, i J. Oltmer (ur.). The Encyclopedia of Migration and Minorities in Europe. From the 17th Century to the Present. New York: Cambridge University Press, 27-33, doi: https://doi. org/10.1017/CBO9780511781841.007

Župarić-Iljić, D. (2016). Iseljavanje iz Republike Hrvatske nakon ulaska u Europsku uniju. Zagreb: Friedrich Ebert Stiftung, www.fes-croatia.org/fileadmin/user_upload/FES_ Iseljavanje_web.pdf. (03. rujna 2017.).

\section{IZVORI}

Facebook stranica grupe »Idemo u Irsku«, https://www.facebook.com/groups/ idemouirsku/

Internetska stranica tvrtke Irish Recruiter, http://www.irishrecruiter.com/zivot-u-irskoj/

Internetska stranica udruge OSMATIZO - Osječka matica iseljenih i zaposlenih Osječana u inozemstvu, http://www.udrugaosmatizo.hr/index.php/home/

Migracija stanovništva Republike Hrvatske u 2016., Priopćenje 7.1.2, Državni zavod za statistiku, Zagreb, 2017, https://www.dzs.hr/Hrv_Eng/publication/2017/07-01-02_ 01_2017.htm

Population and Migration Estimates, CSO statistical release, Central Statistics Office, Cork, 2017, http://www.cso.ie/en/releasesandpublications/er/pme/ populationandmigrationestimatesapril2017

Prebivalište i boravište, Ministarstvo unutarnjih poslova, https://www.mup.hr/gradjani/ prebivaliste-i-boraviste

Statistics on Personal Public Service Numbers Issued, Department of Employment Affaris and Social Protection, https://www.welfare.ie/en/Pages/Personal-PublicService-Number-Statistics-on-Numbers-Issued.aspx.

Youth Unemployment, 2015, Eurostat, http://ec.europa.eu/eurostat/statistics-explained/ index.php/ File:Table_1_Youth_unemployment,_2015Q4_(\%25).png

Zakon o prebivalištu, Narodne novine, 144/12. i 158/13. 


\title{
Contemporary Emigration from Croatia to Ireland with a Special Focus on Young People from Slavonia
}

\author{
Marijeta Rajković Iveta, Tea Horvatin
}

\begin{abstract}
SUMMARY
Following the accession of the Republic of Croatia to the European Union (1 July 2013), a trend of emigration to the Republic of Ireland appeared. Using the theory of push and pull factors and the theory of migration systems (cf. Castles, Miller, 2003; Bretell and Hollifield 2000), the aim of the paper was to explore the context and scope of this wave and to find out the reasons why Ireland has become a popular destination for Croatian citizens. After presenting the macroeconomic and macropolitical context, an overview and comparison of statistical data on emigration from Croatia to Ireland, i.e. the entry of Croatian citizens into the Irish labour market, are presented. After that, mediators in the migration process (international employment agencies, former migrants, and social migrant networks, as well as the role of global communication technologies and social platforms) were researched.
\end{abstract}

The research was conducted from summer 2015 to autumn 2017. The paper is based on ethnological and cultural anthropological qualitative methodology. Ethnographic material, i.e. lived experiences of immigrants, were obtained through face-to-face, semi-structured interviews and virtually - by means of modern technology (Skype conversations, Facebook chats and e-mails). Therefore, field research was also carried out within the contemporary, produced and, in this case, virtual site (cf. Appadurai, 2011: 265). The Croatian Bureau of Statistics annually publishes the report "Migration of the population of Republic of Croatia". These data reveal that the number of emigrated Croatian citizens has increased since the accession of the Republic of Croatia to the European Union in 2013. Croatia's net migration rate is becoming more negative every year and, according to the latest data in 2016, amounted to $-22,451$. That year, 36,436 persons moved abroad - somewhat more men $(54.1 \%)$ than women $(45.9 \%)$. The counties in the Croatian region of Slavonia have the most negative net migration rate (see Migracija stanovništva Republike Hrvatske u 2016. [Migration of Population of Republic of Croatia in 2016], 2017). Considering that the same statistical data show that young people aged between 20 and 34 emigrate the most, migrants from Slavonia in this age group were interviewed for this paper. Although the focus of the research is on the physical territory of Slavonia, this space is also a virtual one, by which we "move away from conventional conceptions of space, turning to social instead of physical space..." (Pleše, 2006: 131). Six young women and four young men were interviewed. Eight of them have university education. They migrated no more than five years ago. The emphasis of the paper is on the ethnography of the particular. We were interested in experiences - how the migrants informed themselves about the possibilities of life and work in Ireland, how and how long had they been preparing for their departure, and what administrative procedures did they go through upon their arrival to Ireland. In addition to these contemporary migrants, we interviewed a migrant who moved from Zagreb to Ireland with her husband in 1998 and since 2013 she has been managing an agency in Dublin through which they find IT professionals from Croatia and mediate in their employment. 
The contemporary wave of emigration was stimulated by the macropolitical context (Croatian accession to the European Union and the opening of the labour market) and the macroeconomic context (the economic development of Ireland compared to high unemployment in Croatia, low salaries, negative economic trends, poor entrepreneurial climate, etc.). The research showed very different data on the number of Croatian citizens in Ireland. The data of the Croatian Bureau of Statistics on the migrations of the population are based on the data of the Administrative Affairs Directorate of the Ministry of the Interior, the records of the change of residence. The research shows that a small number of migrants have completed this civic duty in practice, but the police department does not insist on this either. Ireland is first mentioned in the same data on the emigration of the population towards destination countries in 2016, with the number of 1915 emigrated Croatian citizens. In contrast, the official Irish website welfare.ei publishes statistics on Personal Public Service Number (PPS). This number is mandatory for anyone who wants to work in Ireland and all the immigrants we interviewed applied for it immediately upon their arrival to Ireland. The oldest data on the mentioned website date from July 2000, and the latest are from October 2017. In that period, 18,278 Croatian citizens applied for the PPS number. After the accession of the Republic of Croatia to the European Union, their number increased four times in only one year (2014) and has been increasing continuously since then. During the research, we did not find data on whether these migrants remained living in Ireland permanently.

The microcontext is also exceptionally important for this wave of emigration, especially the networking of migrants and the social migrant network. The research has highlighted the importance of communication technology in generating, transferring and exchanging knowledge between the members of the migration process and in virtual networking. For example, the number of members of the group "Idemo $u$ Irsku" (Eng. Let's go to Ireland) on Facebook is constantly increasing $(19,480$ members in 2015, 40,804 members in 2017). Gathering information over the Internet was the initial preparation for migration for almost all of our informants, but many moved with the help of previous migrants or together with others. Migrants considered the experiences of previous migrants to be the most credible information. Apart from the mentioned Facebook group, the role of the mediators that create mesostructures is also visible on the example of the Irish Recruiter employment agencies from Dublin, EURES (European Job Mobility Portal) and the OSMATIZO association (Osijek's register of emigrants and Osijek citizens employed abroad).

Even though, due to the high unemployment rate in Croatia, which particularly affects young people, some migrants started thinking about leaving already during their education, this desire was turned into reality mostly due to examples from the immediate environment, direct contact with a person who had already emigrated and positive stories heard from friends, fellow citizens and acquaintances. Migrants prepared for the migration briefly - between two weeks and several months. These emigrant experiences demonstrate today's convenience of migrations, i.e. faster and cheaper travel possibilities and the key role of the ubiquitous global communication (cf. Lewellen 2002: 125,126).

The reasons for this migration wave were viewed as a result of the action of the push and pull factors. For the majority of the interviewees, the main motivation for the departure was economic (inability to find employment in their profession, low salaries, resolving their housing issue, and young couples' joint life). There are prominent personal psychological dissatisfactions with most of the interviewees, driven 
by nepotism and corruption at both the local and national level. A negative, almost bitter tone can be observed with two interviewees when they explain the reason for their departure. As the reasons for the migration, migrants also stated: a desire to live in a more liberal environment (with people in same-sex unions, lack of respect for human rights, small conservative environments), curiosity (learning about new cultures and peoples), and opportunities for professional development.

For some migrants, Ireland was the first choice due to topicality, the ubiquity of the subject in the media, friends' recommendations, positive experiences of former migrants, while for others it was a logical decision after considering more options (Germany, Canada, and Australia). Ireland attracted them due to the possibility of finding employment quickly, the open labour market, simple bureaucratic procedures required for work and life, the English language which they know, transport connections/relative proximity (compared to other continents).

The research was conducted on migrants who emigrated after 2013. These were voluntary migrations of young people, most of whom were highly educated but who, at least initially, were willing to do unqualified and low-rated (typically immigrant) jobs. Future research should include early emigrations and other migrants (e.g. family migrations, highly educated migrants /so-called brain drains/ with specific professions, for whom there are indicators that they work in their professions, etc.).

KEY WORDS: Croats in Ireland, emigration from Slavonia, contemporary emigration, (e)migrant experiences 